\title{
PRODUCTIVE PERFORMANCE OF EARLY SUGARCANE GENOTYPES IN RIO GRANDE DO SUL STATE, BRAZIL
}

\author{
Desempenho produtivo de genótipos precoces de cana-de-açucar no estado do Rio Grande do Sul
}

\author{
William Rodrigues Antunes ${ }^{1 *}$; Edgar Ricardo Schöffel2; Sergio Delmar dos Anjos e Silva ${ }^{3}$; Adílson Härter ${ }^{4}$; \\ Alexssandra Dayanne Soares de Campos 5 ; Cândida Raquel Scherrer Montero 6 \\ ${ }^{1}$ Doutorando; PPG em Sistemas de Produção Agrícola Familiar; Universidade Federal de Pelotas; wr_antunes@hotmail.com \\ 2 Professor; Fitotecnia; Universidade Federal de Pelotas; ricardo.schoffel@gmail.com \\ ${ }_{3}^{3}$ Pesquisador; Pesquisa e Desenvolvimento; Embrapa Clima Temperado; sergio.anjos@embrapa.br \\ ${ }^{4}$ Mestrando; PPG em Sistemas de Produção Agrícola Familiar; Universidade Federal de Pelotas; adilsonharter@gmail.com \\ ${ }^{5}$ Mestranda;PPG em Manejo e Conservação do Solo e da Água, Universidade Federal de Pelotas; alexssandra1_sc@yahoo.com.br \\ ${ }^{6}$ Analista; Pesquisa e Desenvolvimento, Embrapa Clima Temperado; cândida.montero@embrapa.br
}

Artigo enviado em 07/02/2017, aceito em 29/05/2017 e publicado em 07/06/2017.

\begin{abstract}
RESUMO: O Brasil é o maior produtor mundial de cana-de-açúcar, sendo o estado do Rio Grande do Sul considerado uma região de expansão da cultura, carecendo de estudos relacionados à adaptabilidade e estabilidade de novos genótipos de cana-de-açúcar. O objetivo deste trabalho foi avaliar a adaptabilidade e estabilidade de genótipos de cana-de-açúcar (Saccharum spp.) de ciclo precoce, no estado do Rio Grande do Sul. Foram avaliados 13 genótipos em delineamento experimental de blocos ao acaso, com três repetições, considerando-se cada combinação município-corte como um ambiente, com a seguinte nomenclatura: A1, cana-planta em Porto Xavier; A2, cana primeira-soca, em Porto Xavier; A3, cana-planta em Salto do Jacuí; A4, cana primeira-soca em Salto do Jacuí; A5, cana-planta em São Luiz Gonzaga; A6, cana primeira-soca em São Luiz Gonzaga; A7, cana-planta em Santa Rosa; A8, cana primeira-soca em Santa Rosa; e A9, cana primeira-soca em São Borja. As variáveis utilizadas para a análise AMMI (Análise de efeitos principais aditivos e interações multiplicativas) foram produtividade de colmos, de açúcar e eficiência da conversão de energia solar em produção. Os resultados revelaram que entre os genótipos de maturação precoce, o RB975932 (G12) foi superior a cultivar testemunha RB855156 em estabilidade, produtividade e eficiência da conversão de energia solar em produção. Os ambientes de teste de maior produtividade foram São Luiz Gonzaga, para primeira soca, e Santa Rosa tanto como cana planta como para primeira soca.
\end{abstract}

Palavras-Chave - adaptação, ambiente, estabilidade, Saccharum spp..

\begin{abstract}
Brazil is the largest producer of sugarcane, and the Rio Grande do Sul state considered a region of expansion of culture, lacking studies related to adaptability and stability of new genotypes of sugarcane. The objective of this study was to evaluate the adaptability and stability of sugarcane genotypes (Saccharum spp.) of early maturing, in Rio Grande do Sul state. We evaluated 13 genotypes in experimental design randomized block with three replications, considering each combination of site and sugarcane cut as an one environment, as follows: E1 sugarcane plant crop in Porto Xavier; E2 - sugarcane first ratoon crop in Porto Xavier; E3 - sugarcane plant crop in Salto do Jacuí; E4 - sugarcane first ratoon crop in Salto do Jacuí; E5 - sugarcane plant crop in São Luiz Gonzaga; E6 - sugarcane first ratoon crop in São Luiz Gonzaga; E7 - sugarcane plant crop in Santa Rosa; E8 - sugarcane first ratoon crop in Santa Rosa and E9 - sugarcane first ratoon crop in São Borja. The variables used for the AMMI analysis (analysis of additive main effects and multiplicative interactions) were the stalks production, the sugar production and the conversion of solar energy into production. The results revealed that among the early maturing genotypes, RB975932 it was superior the witness cultivate RB855156 in stability, productivity and efficiency conversion of solar energy production. The higher productivity test environments were São Luiz Gonzaga, first ratoon, and Santa Rosa, plant crop and first ratoon.
\end{abstract}

Keywords - adaptation, environment, stability, Saccharum spp.. 


\section{INTRODUCTION}

Brazil is the world's largest sugar cane producer, with a cultivated area of 9.0 million hectares and average productivity of $70.0 \mathrm{Mg} \mathrm{ha}^{-1}$ in 2014/15 crop (CONAB, 2015). Rio Grande do Sul State (RS) average productivity is $40.0 \mathrm{Mg} \mathrm{ha}{ }^{-1}$, with sugarcane cultivated in 29 thousand hectares, representing $0.5 \%$ of the national production (IBGE, 2014). Nevertheless sugarcane plays a very important role for family farming, with its activities being a source of income for many families (MALUF et al., 2008). Recently agro-ecological zoning pointed out 1.5 million of hectares aptitude for cultivation in RS state (MANZATTO; BACA; PEREIRA, 2010), which turns sugarcane a promising tillage at this region, specially at the northeast part of the state, where sugarcane processing plants are located.

The evaluation, identification and indication of sugarcane genotypes concerning its productivity and environmental adaptation are extremely important to the sugarcane expansion in RS State. To perform such observations one of the most employed tools used by breeding programs is the study of genotype and environment interaction (CRUZ; CARNEIRO, 2003). This interaction refers to the modification in relative performance of the genotypes due to the environmental differences, one of the most challenging subjects to breeding programs of any species. Among the alternatives to minimize this problem is the choice of cultivars presenting good stability and large adaptation to environments. Studies approaching this topic aim to know the behavior of genotypes concerning its adaptability, capability of genotypes to respond positively to environmental stimulus, and stability, capability of genotypes to perform a predictable behavior due to environmental stimulus (CRUZ; CARNEIRO, 2003).

Studies dealing with genotype environment interaction have been object of several researches in sugarcane breeding programs (BASTOS et al., 2007, GUERRA et al., 2009, VERISSIMO et al., 2012). The interaction evaluation through Additive Main Effects and Multiplicative Interactions analysis (AMMI) is being applied with success in: corn (MIRANDA et al., 2009), soy (POLIZEL et al., 2013, YOKOMIZO et al., 2013), and recently sugarcane (GUERRA et al., 2009, VERISSIMO et al., 2012, FERNANDES JÚNIOR et al., 2013, MATTOS et al., 2013), among others. The use of this method could help to identify highly productive and adapted genotypes, as well as regionalized indication and selection of test sites, in agronomical zoning (GAUCH JUNIOR; ZOBEL, 1996).
The objective of this study was to evaluate the adaptability and stability of sugarcane genotypes (Saccharum spp.) of early maturing, in Rio Grande do Sul state.

\section{MATERIAL AND METHODS}

Research was carried out during 2012/13 and 2013/14 crops. Evaluations were performed in sugarcane experiments established by Embrapa Clima Temperado, developed by Rede Interuniversitária para o Desenvolvimento do Setor Sucroenergético (Ridesa) and released by Universidade Federal do Paraná Sugarcane breeding program. This experiments were located at the following sites: Porto Xavier $\left(27^{\circ} 53^{\prime} \mathrm{S}, 55^{\circ} 10^{\prime} \mathrm{W}\right.$ - altitude $125 \mathrm{~m})$, Salto do Jacuí $\left(29^{\circ} 00^{\prime} \mathrm{S}, 53^{\circ} 13^{\prime} \mathrm{W}\right.$ - altitude $\left.361 \mathrm{~m}\right)$, São Luiz Gonzaga ( $28^{\circ} 22^{\prime} \mathrm{S}, 54^{\circ} 54^{\prime} \mathrm{W}$ - altitude $225 \mathrm{~m}$ ), Santa Rosa $\left(27^{\circ} 50^{\prime} \mathrm{S}, 54^{\circ} 26^{\prime} \mathrm{W}\right.$ - altitude $\left.342 \mathrm{~m}\right)$ and São Borja $\left(28^{\circ} 41^{\prime} \mathrm{S}, \quad 55^{\circ} 57^{\prime} \mathrm{W}\right.$ - altitude $\left.97 \mathrm{~m}\right)$. Every combination of site and sugarcane cut was consider to be one environment, as follows: E1 - sugarcane plant crop in Porto Xavier; E2 - sugarcane first ratoon crop in Porto Xavier; E3 - sugarcane plant crop in Salto do Jacuí; E4 sugarcane first ratoon crop in Salto do Jacuí; E5 sugarcane plant crop in São Luiz Gonzaga; E6 - sugarcane first ratoon crop in São Luiz Gonzaga; E7 - sugarcane plant crop in Santa Rosa; E8 - sugarcane first ratoon crop in Santa Rosa and E9 - sugarcane first ratoon crop in São Borja.

The productive development of 13 early cycle genotypes were evaluated at 9 environments of RS State, sugarcane plant (2012/13) and first ratoon sugarcane (2013/14): RB006996 (G1), RB036145 (G2), RB036152 (G3), RB005935 (G4), RB015868 (G5), RB015895 (G6), RB016910 (G7), RB016916 (G8), RB016918 (G9), RB985867 (G10), RB855156 (G11-control), RB975932 (G12) and RB016913 (G13).

Conventional tillage consisting of one plough and two disc-harrow implement was performed, with furrows spaced $1.40 \mathrm{~m}$. Conventional tillage occurred at the second half of august 2012, six three budded sugarcane sets were used by linear meter, totalizing 18 buds $\mathrm{m}^{-1}$ (ZAMBON; DAROS, 2005). Fertilization was realized considering the soil chemical analysis at each site. Top dressing fertilization was applied in December and January with $90 \mathrm{~kg}$ of $\mathrm{N} \mathrm{ha}^{-1}$. At first ratoon cultivation, fertilization of $30 \mathrm{~kg} \mathrm{ha}^{-1}$ de N, $60 \mathrm{~kg} \mathrm{ha} \mathrm{P}^{-1} \mathrm{P}_{2} \mathrm{O}_{5}$ and $60 \mathrm{~kg} \mathrm{ha} \mathrm{K}^{-1} \mathrm{O}$ was applied for maintenance. Sugarcane plant was harvested in July and September 2013 and first ratoon sugarcane was harvested in July 2014 when the genotypes showed maturation index between 0.85 and 1.0 (CESNIK; MIOCQUE, 2004).

Randomized complete block design was used, experiments containing three repetitions with parcels of 
four to six lines of 10 meters length each. Variables used to run AMMI were: stalk productivity (tons of sugarcane stalks per hectare - TSH, Mg ha-1), sugar productivity (TSSTH, Mg ha ${ }^{-1}$ ) and efficiency of the conversion of solar energy into production (Ef Se, $\mathrm{g} \mathrm{MJ}^{-1}$ ). To calculate these variables the following equations were used (ZAMBON; DAROS, 2005):

Stalk productivity equation:

$$
T S H=\left(\frac{P 10 C}{10}\right) \times\left(\frac{N C P}{10}\right) x\left(\frac{10}{E}\right)
$$

Where: P10C is the mass of 10 stalks (kg); NCP number of stalks per plot; and $\mathrm{E}$ is the space between lines.

Sugar productivity:

$$
T S S T H=\frac{\text { average value of SST } \times \text { TSH }}{100}
$$

Where: SST is the average total soluble solids obtained in three different stalks with a portable digital refractometer, with sampling at the third internode below the breaking point of the apical shoot and third internode above the soil.

To calculate the efficiency of conversion of solar energy into production the equation used by Albuquerque Neto and Peil (2012) and Caron et al. (2012) was adapted:

$$
\text { Ef } S e=\left(\frac{T S H}{R A D}\right) \times 100
$$

Where: RAD is the global solar radiation accumulated from emergence to harvest.

Meteorological data of air temperature, rain and global solar radiation were made available by Instituto

Nacional de Meteorologia (INMET), $8^{\circ}$ Distrito de Meteorologia, measured by automatic stations localized in each city.

Variance analysis, Additive Main Effects and Multiplicative Interactions analysis (AMMI) and biplot graphics were performed by SAS version 9.2 (SAS Institute, Cary, NC, EUA).

An additional theoretical referential was used for genotypes and environment evaluated by AMMI, called genotype and ideal environment (IG and IE). As described by Pacheco et al. (2005), this approach considers that the agronomical superiority of a genotype must be evaluated comparatively to the maximum productivities observed in each environment. Thus, theoretically the ideal genotype would be the one unifying the maximum productivity among the tested environments.

\section{RESULTS AND DISCUSSION}

Joint experimental analysis detected interaction between genotype and environment for all the variables evaluated (Table 1). This results show that the best genotypes in one environment are not necessarily the best in another, thus stability and adaptability analysis by AMMI were performed.

Table 1. Combined variance analysis, for productivity (tons of sugarcane stalks per hectare - TSH, $\mathrm{Mg} \mathrm{ha}^{-1}$ ), sugar productivity

\begin{tabular}{|c|c|c|c|c|c|c|c|c|c|}
\hline \multirow[t]{2}{*}{ Source of variation } & \multicolumn{3}{|c|}{$\mathrm{TSH}$} & \multicolumn{3}{|c|}{ TSSTH } & \multicolumn{3}{|c|}{ Ef Se } \\
\hline & GL & QM & $\operatorname{Pr}>F$ & GL & QM & $\operatorname{Pr}>F$ & GL & QM & $\operatorname{Pr}>F$ \\
\hline Blocks/environment & 16 & 87.8 & 0.4586 & 16 & 4.2 & 0.3588 & 16 & 0.03 & 0.389 \\
\hline Genotypes (G) & 12 & 1571.6 & $0.0001 * *$ & 12 & 49.8 & $0.0001 * *$ & 12 & 0.51 & $0.0001^{* *}$ \\
\hline Environment (E) & 8 & 30863.9 & $0.0001 * *$ & 8 & 822.0 & $0.0001 * *$ & 8 & 11.44 & $0.0001 * *$ \\
\hline Interaction $\mathrm{G} \times \mathrm{E}$ & 96 & 997.5 & $0.0001 * *$ & 96 & 37.6 & $0.0001 * *$ & 96 & 0.32 & $0.0001 * *$ \\
\hline Residual & 232 & 87.8 & - & 232 & 3.9 & - & 232 & 0.03 & - \\
\hline IPCA 1 & 19 & 677.1 & $0.0000^{* *}$ & 19 & 23.4 & $0.0000 * *$ & 19 & 0.23 & $0.0000 * *$ \\
\hline Residual AMMI1 & 77 & 247.4 & $0.0000^{* *}$ & 77 & 9.8 & $0.0000^{* *}$ & 77 & 0.08 & $0.0000^{* *}$ \\
\hline Average error/r & 232 & 29.3 & - & 232 & 1.3 & - & 232 & 0.01 & - \\
\hline
\end{tabular}
(TSSTH, $\mathrm{Mg} \mathrm{ha}^{-1}$ ), and efficiency of the conversion of solar energy into production (Ef Se, $\mathrm{g} \mathrm{MJ}^{-1}$ ) of 13 early maturing sugarcane genotypes.

**Significant at $1 \%(\mathrm{p}<=0.01)$. Genotypes evaluated in nine environments, in the northeast region of RS state, with the split of the original interaction GxE by AMMI model. 
Genotypes situated closest to the origin of the GxE interaction axis, for TSH variable were: RB016916 (G8), RB985867 (G10), RB855156 (G11, Control) and RB975932 (G12). This confers to theses genotypes high phenotypical stability for TSH and indicates wide adaptation to the tested environments (Figure 1 a). Among these the following genotypes distinguished: G8, G11 and G12, with TSH superior to the general average (114.6 Mg $\left.\mathrm{ha}^{-1}\right)$, reaching the seventh $\left(115.3 \mathrm{Mg} \mathrm{ha}^{-1}\right)$, sixth $(117.6 \mathrm{Mg}$ $\left.\mathrm{ha}^{-1}\right)$ and second $\left(124.3 \mathrm{Mg} \mathrm{ha} \mathrm{h}^{-1}\right)$ general positions, respectively.

In general, five genotypes (G13, G12, G4, G5 and G7) reached stalk productivity (TSH) $(8.0 ; 5.7 ; 1.0 ; 0.4$ and $0.08 \%$, respectively) over the control (G11). Nevertheless, only one of these genotypes (G12) showed stability allied to stalk productivity.

In Rio Grande do Sul State, Verissimo et al. (2012) has obtained similar results, verifying 10 genotypes with stalk productivity greater than the control, with an average gain of $5.2 \%$ in productivity, but only three genotypes showed productive stability.

Genotypes with lower stability for TSH were RB015895 (G6), RB006996 (G1), RB016913 (G13), RB005935 (G4), RB036145 (G2) and RB036152 (G3). These showed greater score at the interaction axis IPCA1 indicating the variation in stalk productivity among environments.

These results were similar with the ones found by Verissimo et al. (2012), who observed genotypes with low stability, that is, low foreseeability of stalk productivity. G13 genotype was distinct for showing higher average of $\mathrm{TSH}$, reaching the first general position $\left(127.0 \mathrm{Mg} \mathrm{ha}^{-1}\right)$.

As for sugar productivity (TSSTH) - (Figure $1 \mathrm{~b}$ ), the most stable genotypes and adapted to the locations tested were: RB016916 (G8), RB985867 (G10), RB855156 (G11) and RB975932 (G12). These were set closest to the IPCA1 interaction axis, maintaining stability and adaptation shown by these genotypes for TSH. This way, the elevated productivity of stalks and sugar evidences the great potential of these genotypes.

Genotypes G8, G11 (Control) and G12 showed TSSTH superior to the general average $\left(22.2 \mathrm{Mg} \mathrm{ha}^{-1}\right)$, reaching the fifth $\left(22.4 \mathrm{Mg} \mathrm{ha}^{-1}\right)$, third $\left(23.1 \mathrm{Mg} \mathrm{ha}^{-1}\right)$ and first (24.8 $\mathrm{Mg} \mathrm{ha}^{-1}$ ) general position, respectively.

Similar results for sugar productivity and stability of RB855156 were obtained by Mattos et al. (2013), indicating excellent adaptation and sugar accumulation. RB855156 was also used as control on the following research Guerra et al. (2009), in Paraná State, and by Verissimo et al. (2012), in Rio Grande do Sul State, in which it presented high sugar productivity although it was not stable for the evaluated locations.
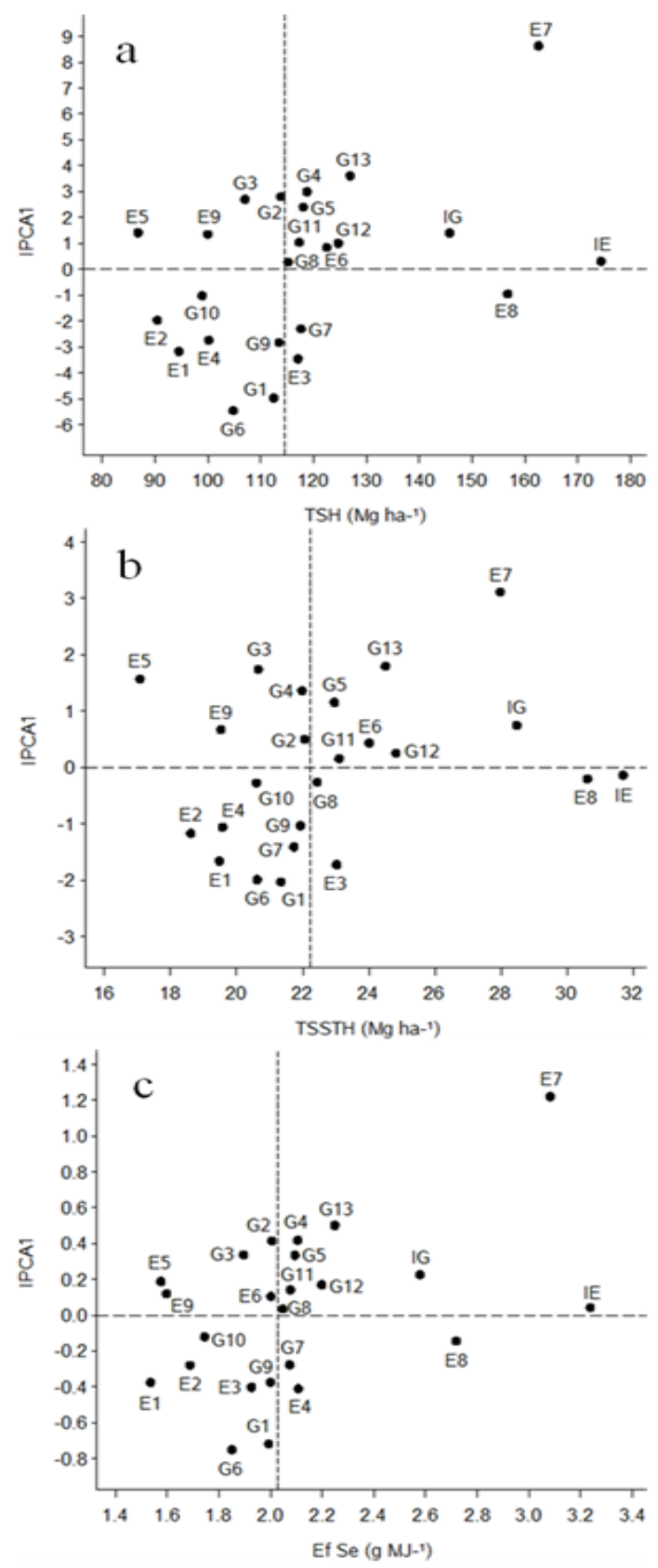

Figure 1. Biplot AMMI1 for: stalk productivity (TSH), sugar productivity (TSSTH) and efficiency of the conversion of solar energy into production (Ef Se) of 13 early maturin $\mathrm{g}$ sugarcane genotypes, evaluated in nine locations, at the northeast region of RS state. E1-E9, site and stage (plant or first ratoon); G1-G13, genotype identification; IE, ideal environment; and IG, ideal genotype. 
As a rule, the genotypes G12 and G13 showed sugar productivity (TSSTH) higher than the control (G11), overcoming it in 7.4 and $6.1 \%$, respectively. Only the G12 was productive and stable, which also happened for stalk productivity (TSH). Sugar productivity, stability and adaptation of early maturing sugarcane genotypes overcoming the control RB855156 were also identified by Zeni Neto et al. (2008), indicating the presence of promising early maturing sugarcane genotypes with an average gain of $5.7 \%$ in productivity when compared with the control.

RB006996 (G1)， RB015895 (G6), RB036152 (G3), RB016913 (G13) and RB005935 (G4) genotypes contributed mostly to the genotype environment interaction (low stability). These genotypes showed the greatest score magnitude in the IPCA1 interaction axis, which indicates there was variation for sugar production among locations. Among these, G13 showed high average of TSSTH reaching the second general position $(24.5 \mathrm{Mg}$ $\left.\mathrm{ha}^{-1}\right)$, because of its potential to accumulate sugar. In Paraná State, Mattos et al. (2013) observed similar behavior where a genotype showed high sugar productivity allied to low stability and this suggests variation among cultivated locations, although this condition was not identified by the authors.

For the efficiency of the conversion of solar energy into production (Ef Se) the most adapted and stable genotypes were: RB016916 (G8), RB985867 (G10), RB855156 (G11) and RB975932 (G12) (Figure $1 \mathrm{c}$ ). These genotypes were positioned closest to the origin of the IPCA1 interaction axis as verified for the other variables (TSH and TSSTH). The genotypes G8, G11 and G12 showed superiority to the general average $\left(2.03 \mathrm{~g} \mathrm{MJ}^{-1}\right)$, achieving the seventh $\left(2.05 \mathrm{~g} \mathrm{MJ}^{-1}\right)$, fifth $\left(2.08 \mathrm{~g} \mathrm{MJ}^{-1}\right)$ and second $\left(2.20 \mathrm{~g} \mathrm{MJ}^{-1}\right)$ general position, respectively, qualifying them as widely adapted to the tested environments.

In general, four genotypes (G13, G12, G4 and G5) were efficient to convert solar energy into production, overcoming the control (G11) in 8.2; 5.8; 0.96 and $0.96 \%$ respectively. Of these only G12 was stable and efficient, corroborating with the results of the variables TSH and TSSTH.

The genotypes that contributed to the interaction genotype and environment (low stability) were RB015895 (G6), RB006996 (G1), RB016913 (G13), RB036145 (G2), RB005935 (G4) and RB036152 (G3), since they presented the greatest score magnitude in the IPCA1 interaction axis, indicating variation of efficiency of the conversion of solar energy into production among environments, as verified for the variables TSH and TSSTH. Among them G13 genotype is the most efficient on the use of solar energy into production $\left(2.25 \mathrm{~g} \mathrm{MJ}^{-1}\right)$.
Because of its high stalk (TSH) and sugar productivities (TSSTH) and efficient conversion of solar energy into production (Ef Se), RB016913 genotype (G13) has reached the first $\left(127.0 \mathrm{Mg} \mathrm{ha}^{-1}\right)$, second $\left(24.5 \mathrm{Mg} \mathrm{ha}^{-1}\right)$ and first $\left(2.25 \mathrm{~g} \mathrm{MJ}^{-1}\right)$ general position respectively. Among all, RB016913 was the most proximate to ideal genotype (IG). On the other hand, considering stability, productivity and efficiency of the conversion of solar energy into production we can highlight RB016916 genotype (G8), that showed stalk, sugar and Ef Se of $0.61 ; 0.90$ and $0.99 \%$ above the general average, being the most stable genotype among all, without overcoming the control (G11).

On the environments E3 (Salto do Jacuí, plant crop), E6 (São Luiz Gonzaga, first ratoon crop), E7 (Santa Rosa, plant crop) and E8 (Santa Rosa, first ratoon crop), genotypes showed TSH and TSSTH productivities superior to the general average. However, only location E6 and E8 show high stability (proximity to the IPCA1 interaction axis), conferring them better adaptation and minor productive variation. Efficiency of the conversion of solar energy into production (Ef Se), greatest distinction were set for environments E4 (Salto do Jacuí, plant crop), E7 (Santa Rosa, plant crop) and E8 (Santa Rosa, first ratoon crop), with values above the general average. Otherwise, only environment E8 was stable approximating to the IPCA1 interaction axis, which confers to this a better adaptation and efficiency of conversion of solar energy into production of the tested genotypes.

Environments that contributed the most to the interaction genotype and environment (low stability) were E1 (Porto Xavier, plant crop), E3 (Salto do Jacuí, plant crop) and E7 (Santa Rosa, plant crop), for presenting the greatest score magnitude on the IPCA1 interaction axis, which evinces the great variation in stalk and sugar productivity, and efficiency of conversion of solar energy into production of the genotypes at this environments.

According to Oliveira, Duarte and Pinheiro (2003), environmental stability informs about the reliability of the genotype ranking in a certain tested location, in relation to the average classification of the tested environments. Thus, production environment with high productive stability, as observed in E6 (São Luiz Gonzaga, first ratoon crop) and E8 (Santa Rosa, first ratoon crop), could have its results extrapolated to other environments. As for example being used at the initial phase of a sugarcane breeding program consisting of a great number of genotypes without repetition and planted in one site only. On the other hand, high productive instability, that is, high contribution to genotype and environment, such as E3 (Salto do Jacuí, plant crop) and E7 (Santa Rosa, plant crop), could be used in genotype competition trial, therefore facilitating the selection of superior genotypes. 
E7 environment showed maximum temperature of $37.4{ }^{\circ} \mathrm{C}$, average of $20.7{ }^{\circ} \mathrm{C}$ and minimum of $0.9^{\circ} \mathrm{C}$, accumulated global solar radiation of $5273.8 \mathrm{MJ} \mathrm{m}^{-2}$ and accumulated rainfall of $1613.0 \mathrm{~mm}$, showing the greatest drought in November 2012, reaching 17 days. E8 environment had maximum temperature of $36.1{ }^{\circ} \mathrm{C}$, average of $19.1{ }^{\circ} \mathrm{C}$ and minimum of $2.8{ }^{\circ} \mathrm{C}$, accumulated global solar radiation of $5767.1 \mathrm{MJ} \mathrm{m}^{-2}$ and accumulated rainfall of $1831.8 \mathrm{~mm}$, showing the greatest drought in October 2013, reaching 11 days.

It is believed that the greatest stalk productivity of the early maturing genotypes in E7 is due to plant crop cycle being more productive than first ratoon cycle (E8), as well as for the occurrence of favorable temperatures for vegetative growing, over the ones favorable to sugar accumulation, and, as a result this was the most efficient environment on using solar energy into production. On the other hand, the genotypes on E8 environment showed the greatest sugar productivity, suggesting improved maturation, as a possible consequence to the greater number of days with temperatures below $16.0{ }^{\circ} \mathrm{C}$, favorable to the maturation process.

\section{CONCLUSIONS}

Sugarcane genotypes evaluated show interaction with cultivation environments.

RB975932 (G12) genotype shows elevated stalk and sugar productivity, efficiency on the conversion of solar energy into production, stability and wide adaptation to the environment of the northeast region of Rio Grande do Sul State.

Santa Rosa, RS, is the most productive environment both in plant crop cycle as for first ratoon crop cycle.

\section{ACKNOWLEDGMENTS}

To the Financier of Studies and Projects (Finep), the Brazilian Agricultural Research Corporation (Embrapa CPACT), to Petroleum Brazilian S.A. (Petrobras) and the Higher Education Personnel Improvement Coordination (Capes), for financial support.

\section{REFERENCES}

AlBuQuerque NETO, A. A. R de.; PEIL, R. M. N. Produtividade biológica de genótipos de tomateiro em sistema hidropônico no outono/inverno. Horticultura Brasileira, v. 30, n. 4, p. 613-619, out/dez. 2012.
BASTOS, I .T. BARBOSA, M. H. P.; RESENDE, M. D. V DE.; PETERNELLI, L. A.; SILVEIRA, L. C. I da.; DONDA, L. R.; FORTUNATO, A. A.; COSTA, P. M. A.; FIGUEIREDO, I. C. R de. Avaliação da interação genótipo $\mathrm{x}$ ambiente em cana-de-açúcar via modelos mistos. Pesquisa Agropecuária Tropical, v. 37, n. 4, p. 195-203, jan/out. 2007.

CARON, B. O.; SOUZA, V. Q.; TREVISAN, R.; BEHLING, A.; SCHMIDT, D.; BAMBERG, R.; ELOY, E. Eficiência de conversão da radiação fotossinteticamente ativa interceptada em fitomassa de mudas de eucalipto. Revista Árvore, v. 36, n. 5, p. 833-842, set/out. 2012.

CESNIK, R; MIOCQUE, J. Melhoramento da cana-de-açucar. Brasília, DF: Embrapa Informação Tecnológica, 2004, 307p.

COMPANHIA NACIONAL DE ABASTECIMENTO (Conab). Acompanhamento da safra brasileira: cana-de-açúcar, monitoramento agrícola, segundo levantamento agosto/2015 - Companhia Nacional de Abastecimento. Brasília, p. 1-33: Conab 2015. Avaliable at: <http://www.conab.gov.br/OlalaCMS/uploads/arquivos /14_04_10_09_00_57_boletim_cana_portugues__4o_lev_-_13.pdf>. Acess on: 18 Set. 2015.

CRUZ, C. D.; CARNEIRO, P. C. S. Modelos biométricos aplicados ao melhoramento genético. Viçosa: UFV, 2003. 579 p.

FERNANDES JUNIOR, A. R.; ANDRADE, J. A. C.; SANTOS, P. C.; HOFFMANN, H.; CHAPOLA, R. G.; CARNEIRO, M. S.; CURSI, D. E. Adaptabilidade e estabilidade de clones de cana-de-açúcar. Bragantia, v. 72, n. 3, p. 208-216. 2013.

GAUCH JUNIOR, H. G.; ZOBEL, R. W. Optimal replication in selection experiments. Crop Science, Madison, v. 36, n. 4, p. 838-843, mar/jul. 1996.

GUERRA， E. P.; OLIVEIRA， R. A.; DAROS, E.; ZAMBON, J. L. C.; IDO, O. T.; BESPALHOK FILHO, J. C. Stability and adaptability of early maturing sugarcane clones by AMMI analysis. Crop Breeding and Applied Biotechnology, v. 9, p. 260-267, abr/ago. 2009.

INSTITUTO BRASILEIRO DE GEOGRAFIA E ESTATÍSTICA (IBGE). Levantamento sistemático da produção agricola: Julho de 2014. Avaliable at: < http://www.ibge.gov.br/home/estatistica/indicadores/a gropecuaria/lspa/default publ completa.shtm $>$. Acess on: 08 Set. 2015. 
MALUF, J. R. T.; WESTPHALEN, S. L.; MATZENAUER, R.; MALUF, D. E. Zoneamento agroclimático atualizado para a cultura da cana-de-açúcar no Estado do Rio Grande do Sul, visando à produção de açúcar e álcool. Porto Alegre: Fepagro. 2008. 78 p.

MANZATTO, C. V.; BACA, J. F. M.; PEREIRA, S. E. M. Zoneamento agroecológico da cana-de-açúcar: abordagem metodológica para integração temática de grandes áreas territoriais. In: PRADO, R. B.; TURETTA, A. P. D.; ANDRADE, A. G. (Eds.). Manejo e conservação do solo e da água no contexto das mudanças ambientais. Rio de Janeiro: Embrapa Solos. 2010. p. 193-214.

MATTOS, P. H. C.; OLIVEIRA, R. A.; BESPALHOK FILHO, J. C.; DAROS, E.; VERISSIMO, M. A. A. Evaluation of sugarcane genotypes and production environments in Paraná by GGE biplot and AMMI analysis. Crop Breeding and Applied Biotechnology, v. 13, p. 8390, nov/fev. 2013.

MIRANDA, G. V.; SOUZA, L. V.; GUIMARÃES, L. J. M.; NAMORATO, H.; OLIVEIRA, L. R.; SOARES, M. O. Multivariate analyses of genotype $\mathrm{x}$ environment interaction of popcorn. Pesquisa Agropecuária Brasileira, v. 44, n. 1, p. 45-50, set/dez. 2009.

OLIVEIRA, A. B de.; DUARTE, J. B.; PINHEIRO, J. B. Emprego da análise AMMI na avaliação da estabilidade produtiva em soja. Pesquisa Agropecuária Brasileira, v.38, n. 3 p. 357-364, mar/mar. 2003.
PACHECO, R. M.; DUARTE, J. B.; VENCOVSKY, R.; PINHEIRO, J. B.; OLIVEIRA, A. B. Use of supplementary genotypes in AMMI analysis. Theoretical and Applied Genetics, v. 110, p. 812-818, set/fev. 2005.

POLIZEL, A. C.; JULIATTI, F. C.; HAMAWAKI, O. T.; HAMAWAKI, R. L.; GUIMARÃES, S. L. Adaptabilidade e estabilidade fenotípica de genótipos de soja no estado do Mato Grosso. Bioscience Journal, v. 29, n.4, p. 910-920, jul/ago. 2013.

VERISSIMO, M. A. A.; SILVA, S. D. A.; AIRES, R. F.; DAROS, E.; PANZIEIRA, W. Adaptabilidade e estabilidade de genótipos precoces de cana-de-açúcar no Rio Grande do Sul. Pesquisa Agropecuária Brasileira, v.47, n. 4, p.561-568, jan/mar. 2012.

YOKOMIZO, G. K.; DUARTE, J. B.; VELLO, N. A.; UNFRIED, J. R. Análise AMMI da produtividade de grãos em linhagens de soja selecionadas para resistência à ferrugem asiática. Pesquisa Agropecuária Brasileira, v. 48, n.10, p. 1376-1384, mai/set. 2013.

ZAMBON, J. L. C.; DAROS, E. Manual de experimentação para a condução de experimentos. Curitiba: UFPR. 2005. 49 p.

ZENI NETO, H.; DAROS, E.; ZAMBON, J. L. C.; BESPALHOK FILHO, J. C.; OLIVEIRA, R. A.; WEBER, E. Adaptabilidade e estabilidade fenotípica de clones precoces de cana-de-açúcar no estado do Paraná. Scientia Agraria, v.9, n.3, p. 283-289, dez/mai. 2008. 